\title{
Fast as smell: the need for speed in detection and discrimination of odors
}

Brian H Smith

From 1st International Workshop on Odor Spaces

Hannover, Germany. 4-7 September 2013

Abstract not submitted for online publication.

Published: 16 April 2014

doi:10.1186/2044-7248-3-S1-023

Cite this article as: Smith: Fast as smell: the need for speed in detection and discrimination of odors. Flavour 2014 3(Suppl 1):O23.

Submit your next manuscript to BioMed Central and take full advantage of:

- Convenient online submission

- Thorough peer review

- No space constraints or color figure charges

- Immediate publication on acceptance

- Inclusion in PubMed, CAS, Scopus and Google Scholar

- Research which is freely available for redistribution

Submit your manuscript at www.biomedcentral.com/submit

\section{() Biomed Central}

